\title{
Agnieszka Kretek-Kamińska
}

\section{Aktywność społeczna młodych mieszkańców wsi (na przykładzie członków LGD)}

\section{Wstęp}

Współczesne koncepcje demokracji - i funkcjonującego w jej ramach społeczeństwa - akcentują rosnącą rolę obywateli w kształtowaniu sfery publicznej. Uczestnictwo możliwie szerokich i zróżnicowanych grup społecznych w życiu społeczno-politycznym (państwa, regionu, społeczności lokalnej) nie tyle wspomaga realizację zadań i działań podejmowanych przez władze, ile decyduje o ich powodzeniu (od legitymizacji decyzji władz do podejmowania konkretnych aktywności na rzecz wdrażania określonych rozwiązań). Partycypacja publiczna obywateli, wyrażająca się w ich powszechnym uczestnictwie w wyborach, debatach, konsultacjach publicznych i innych formach bezpośredniej komunikacji/wpływu na decyzje przedstawicieli różnych szczebli administracji publicznej oraz partycypacja wspólnotowa, realizowana w przedsięwzięciach podejmowanych w ramach i na rzecz środowisk, w których na co dzień się funkcjonuje, jest warunkiem koniecznym sprawnego funkcjonowania instytucji demokratycznych. Udział obywateli w procesach decyzyjnych, dotyczących kształtowania polityki państwa, formy i zakresu przedsięwzięć realizowanych przez władze, kształtu i sposobu funkcjonowania sfery publicznej stwarza szanse zwiększenia adekwatności realizowanych projektów, programów i strategii działania do potrzeb odbiorców, do których są kierowane, a tym samym także ich skuteczności (np. Florida 2010; Fukuyama 1997; Putnam 2008; Sartori 1998; Triglia 2001 czy w Polsce: Działek 2011; Furmankiewicz 2013; Herbst 2007; Kaźmierczak 2011). 
Co za tym idzie, celem współczesnych państw demokratycznych

powinno być [...] uzupełnianie politycznej demokracji „demokracją społeczną” - rozszerzaniem procesu demokratyzacji ze sfery politycznej (określającej jednostki jako obywateli) do sfery obywatelskiej (civil), gdzie na obywateli patrzy się jako na mężczyzn i kobiety, przedsiębiorców i robotników, nauczycieli i uczniów, producentów i konsumentów (Herbst, 2005: 20),

aktywizacja ich zasobów jednostkowych (kapitału ludzkiego) oraz ponad-, czy międzyjednostkowych (kapitału społecznego) w procesach współdecydowania i współrządzenia. Jak pisze Antoni Sułek:

demokracja potrzebuje obywateli, którzy chcą i potrafią obsługiwać jej mechanizmy, zaś obywatele pozbawieni umiejętności społecznych nie skorzystają z oferowanych im przez demokrację możliwości wyrażania swych preferencji i realizacji interesów. Rozwój demokracji i przyrost umiejętności obywatelskich w społeczeństwie wzmacniają się nawzajem. Miejscem nabywania doświadczeń i umiejętności społecznych są dobrowolne organizacje, działania i kontakty, które wypełniają przestrzeń między jednostką a społeczeństwem, obywatelem a państwem; ich sieć tworzy to co nazywamy samoorganizującym się społeczeństwem obywatelskim (Sułek 2013: 275).

A zatem z jednej strony partycypacja w procedurach demokratycznych i opartych na nich decyzjach dotyczących sfery publicznej wzmacnia i ugruntowuje kompetencje obywatelskie, uobecnia oddziaływanie kapitału społecznego (stanowi jego wymierny przejaw) i oferuje płaszczyznę rozwijania kapitału ludzkiego. $Z$ drugiej strony tylko odpowiedni poziom wszystkich tych zasobów stwarza szansę efektywnej realizacji wspomnianych procedur. Podejmowanie świadomych decyzji w sprawach publicznych, działanie w ramach i na rzecz wspólnoty skupiającej podmioty o różnych potrzebach, możliwościach i celach, wymaga od jednostek konkretnych przekonań i kompetencji. Włączanie obywateli w proces „współrządzenia” opiera się na założeniu, że mają oni nastawienie, wiedzę i umiejętności umożliwiające im zdobycie informacji na temat kwestii, o której chcą współdecydować, uznanie za wartość faktu, że istnieją różne możliwe perspektywy postrzegania tej kwestii i że należy je co najmniej poznać, wyartykułowanie własnego stanowiska 
i przewidywanie wynikających z niego konsekwencji. Co warte podkreślenia, te same kompetencje warunkują także sukces jednostek w innych sferach życia. Jak wskazują badania

w gospodarce opartej na wiedzy pozycja jednostki na rynku pracy i jej konkurencyjność, a także sprawne funkcjonowanie w społeczeństwie, jest determinowane przez zdolność i chęć do szybkiego przyswajania nowoczesnych technologii, w tym informacji i ich umiejętnego używania (Grabowska et al. 2013: 98).

Zarówno dla efektywnego działania w sferze zawodowej, jak i społecznej szczególne znaczenie mają: elastyczność i chęć uczenia się, umiejętności funkcjonowania w grupie i komunikacji międzyludzkiej, a także kreatywność i przedsiębiorczość (Perspektywa uczenia się przez cale życie, 2013: 28-29) oraz zaufanie do innych ludzi, organizacji, władz (Putnam 2008; Sułek 2013).

\section{Poziom aktywności społeczno-politycznej młodzieży wiejskiej na tle aktywności społeczeństwa polskiego}

W świetle powyższych rozważań oczywista wydaje się konstatacja, że to właśnie wymienione powyżej dyspozycje, kompetencje i zasoby (jako element/przejaw kapitałów ludzkiego i społecznego) postrzegane są współcześnie także jako czynniki znacząco oddziałujące na poziom konkurencyjności różnych obszarów, istotne determinanty rozwoju regionalnego i lokalnego.

Niestety, mimo że we wszystkich kategoriach społecznych odnotowuje się wzrost kapitału ludzkiego ${ }^{33}$ (por. Grabowska et al. 2013), wciąż nie jest on wystarczająco dobrze dostosowany do wymogów współczesnego rynku pracy. Pracodawcy obok braków wiedzy i umiejętności, ściśle związanych z wykonywaniem określonego zawodu,

33 „Wynika on przede wszystkim z utrzymywania się rosnącego trendu korzystania z nowoczesnych technologii informatycznych, bowiem inne składowe pomiaru kapitału (znajomość języka angielskiego, kształcenie ustawiczne) wskazują na stagnację bądź nawet regres odpowiednich wartości” (Grabowska et al. 2013: 99). 
najczęściej zwracają uwagę na niedobory kompetencji: samoorganizacyjnych (samoorganizacja pracy i przejawianie inicjatywy, terminowość, przedsiębiorczość, odporność na stres); [...] interpersonalnych - kontakty z ludźmi i współpraca w grupie (Górniak 2013: 53).

Co istotne z punktu widzenia podjętego w artykule tematu, mieszkańcy obszarów wiejskich charakteryzują się zarówno najniższym poziomem kapitału ludzkiego, jak i najniższą aktywnością w zakresie podnoszenia własnych kwalifikacji i umiejętności. I tak, w latach 20112013 w jakiejkolwiek aktywności związanej z podnoszeniem swoich kwalifikacji zawodowych czy innych umiejętności uczestniczyło niespełna $10 \%$ osób w wieku 25 lat i więcej, przy czym aktywność taką przejawiało jedynie około 5-7\% mieszkańców wsi (od 8-10\% mieszkańców miast liczących od 20 do 200 tys. mieszkańców do ponad 20\% dla miast mających powyżej 500 tys. mieszkańców) (Strzelecki et al. 2013: 136-137). Analogiczny kierunek zależności, ale jeszcze większe dysproporcje między poszczególnymi kategoriami, występują przy zestawieniu wielkości miejsca zamieszkania i odsetka osób w wieku 2024 lata, korzystających z usług edukacyjnych świadczonych w trybie szkolnym i pozaszkolnym. O ile dla wsi wynosi on $48 \%$, o tyle dla miast rośnie od 52\% w przypadku miast liczących poniżej 20 tys. mieszkańców, aż do 79\% w przypadku miast mających powyżej 500 tys. mieszkańców (Grabowska et al. 2013: 85).

Także analizy dotyczące kapitału społecznego Polaków nie napawają optymizmem. Ze względu na skłonność do stowarzyszania się (wyrażoną jako przeciętna liczba organizacji, do których należą respondenci w wieku 16 i więcej lat ${ }^{34}$ ), a także pod względem - sprzyjającego jej - ogólnego zaufania Polska zajmowała jedno z ostatnich miejsc wśród krajów objętych badaniem European Social Survey (ESS) w 2006 i 2012 r. (Czapiński 2013: 286). Cykliczne badania ogólnopolskie realizowane w ramach projektu

34 W Polsce w 2013 r. członkami ,jakichś organizacji, stowarzyszeń, partii, komitetów, rad, grup religijnych, związków lub kół" było 13,7\% badanych: 10,3\% należało tylko do jednego stowarzyszenia; 2,5\% do dwóch, a 0,9\% do dwóch lub więcej; 86,3\% nie należy do żadnej organizacji (por. Sułek 2013: 278). 
Diagnoza Społeczna. Warunki i Jakość Życia Polaków wskazują że stosunkowo nielicznie uczestniczą oni w organizacjach, [...] oddolnych inicjatywach społecznych, w zebraniach publicznych czy wolontariacie (Sułek 2013: 283).

Według badań nad zaangażowaniem społecznym obywateli, realizowanych przez stowarzyszenie Klon/Jawor ${ }^{35}$, ich aktywność (rozumiana jako zaangażowanie w pracę na rzecz osób lub organizacji (w tym na rzecz Kościoła bądź związku wyznaniowego) w ramach tychże organizacji lub poza nimi bez pobierania wynagrodzenia za wykonane działania)

utrzymuje się od kilku lat na podobnym poziomie: aktywna jest około jedna trzecia społeczeństwa, przy czym w „formalny” wolontariat zaangażowanych było w 2013 roku $18 \%$ (nieco więcej niż w latach poprzednich), a w działania na rzecz osób spoza kręgu rodziny i znajomych lub na rzecz okolicy $27 \%$ badanych (podobnie jak w latach poprzednich) (Zaangażowanie... 2014: 7).

Z kolei wyniki badań przeprowadzonych w ramach Diagnozy Spotecznej ${ }^{36}$, poza tym, iż wskazują, że odsetek zrzeszonych jest jeszcze niższy (13,7\% ogółu badanych) informują także, że lekko i nieregularnie wzrasta on wraz z wielkością miejsca zamieszkania - od 8,5\% na wsi do 12,9\% w wielkich miastach (Sułek 2013: 279). Podobną prawidłowość, polegającą na tym, że „ogólnie mieszkańcy miast angażowali się nieznacznie częściej i przeznaczali więcej czasu na działania na rzecz innych niż mieszkańcy wsi" odnotowuje w swoich badaniach dotyczących wolontariatu w organizacjach i poza nimi także Główny Urząd Statystyczny ${ }^{37}$ (2013: 49). Dodatkowo przywołane badania wykazały, że największe zróżnicowanie w tym zakresie występuje wśród osób najmłodszych, które nie ukończyły jeszcze 25. roku życia. Młodzi ludzie w miastach liczących powyżej 100 tys. mieszkańców nieco częściej podejmowali pracę społeczną $(11,5 \%)$ niż ich koledzy i koleżanki ze wsi

35 Badanie zrealizowano na ogólnopolskiej, reprezentatywnej próbie 1005 Polek i Polaków, którzy ukończyli 15. rok życia.

${ }^{36}$ W 2013 r. przebadano 12355 gospodarstw domowych z 36293 członkami i indywidualnie 26307 członków tych gospodarstw w wieku 16 i więcej lat.

37 Badanie zrealizowano na reprezentatywnej próbie 13460 osób w wieku 15 lat i więcej. 
i mniejszych miast (średnio 9,7\%) (GUS 2013: 27). Co więcej,

średni czas indywidualnej pracy niezarobkowej [świadczonej poza organizacjami - przyp. A. K.-K.] wśród młodzieży mieszkającej w miastach był niemal 3-krotnie wyższy niż wśród młodzieży mieszkającej na wsi (15 godzin w mieście wobec 6 godzin na wsi), jednak w tej grupie wiekowej odsetki osób indywidualnie świadczących pracę niezarobkową zarówno na wsi, jak i w mieście kształtowały się na zbliżonym poziomie (GUS 2013: 49).

Dłuższy czas poświęcany na pracę niezarobkową przez młodzież miejską w stosunku do młodzieży wiejskiej według raportu GUS

prawdopodobnie wynika z faktu, że dzieci mieszkające na wsi są bardziej obciążone pracą na rzecz własnego gospodarstwa domowego, w tym pracą na roli, w związku z czym mają mniej czasu wolnego, który mogą przeznaczyć na pomoc innym (GUS 2013: 49).

\section{Mimo to właśnie}

w najmłodszej badanej grupie wiekowej (15-17 lat) udział osób poświęcających czas na wspomaganie organizacji lub instytucji był niemal dwukrotnie wyższy niż w całej badanej populacji i wyniósł 18,9\% [Niestety] w kolejnych dwóch przedziałach wiekowych zainteresowanie pracą społeczną w organizacjach lub instytucjach znacząco spada (18-24 lata - 11,8\%, 25-34 lata-8,9\%), osiągając minimum w momencie wchodzenia w życie zawodowe i zakładania rodziny (GUS 2013: 27-28).

Zróżnicowany poziom uczestnictwa w działalności organizacji, zdiagnozowany w badaniach GUS, zaprezentowano w tabeli 13.

Podejmowaniu aktywności społecznej (rozumianej jako nieodpłatna praca na rzecz innych osób lub organizacji) towarzyszą zróżnicowane motywacje. Według badań zrealizowanych przez stowarzyszenie Klon/ /Jawor do najważniejszych (ze względu na częstotliwość ich występowania) należą: korzyści psychologiczne - chęć bycia potrzebnym, przydatnym i odczuwanie przyjemności z wykonywanych działań (wskazane łącznie przez 2/3 badanych), wartości i normy społeczne nakazujące pomagać innym, współdziałać, robić rzeczy pożyteczne, ulepszać świat itp. (wskazywane przez 65\% badanych), relacje towarzyskie oraz społeczne - możliwość zyskania szacunku i uznania, bycia w grupie, ale 
Tabela 13

Osoby świadczące pracę niezarobkową w ramach organizacji lub instytucji w ciągu czterech tygodni poprzedzających badanie, według wieku

\begin{tabular}{|c|c|c|}
\hline Kategorie wiekowe (w latach) & Wieś (w \%) & Miasto (w \%) \\
\hline $15-17$ & 17,4 & 20,2 \\
\hline $18-24$ & 12,1 & 11,6 \\
\hline $25-34$ & 6,3 & 10,5 \\
\hline $35-44$ & 8,6 & 9,4 \\
\hline $45-54$ & 11,3 & 10,4 \\
\hline $55-64$ & 10,1 & 9,5 \\
\hline 65 lat i więcej & 9,1 & 8,7 \\
\hline
\end{tabular}

Źródło: opracowanie na podstawie raportu GUS Wolontariat w organizacjach i inne formy pracy niezarobkowej poza gospodarstwem domowym - 2011. Studia i analizy statystyczne, Warszawa.

także wypracowania relacji wzajemności, swego rodzaju zobowiązania otoczenia do „odpłacenia” respondentowi w przyszłości pomoca, gdyby jej potrzebował (łącznie 51\% wskazań), bezpośrednie osobiste korzyści w postaci nowych doświadczeń i umiejętności (44\% wskazań), pasja, samorealizacja (36\% wskazań), oportunizm - dopasowanie do oczekiwań otoczenia (29\% wskazań). Z punktu widzenia analiz podjętych $\mathrm{w}$ artykule istotne wydaje się podkreślenie, że dla najmłodszych uczestników przytoczonych badań (mających 15-26 lat) szczególne znaczenie miały: korzyści psychologiczne, wskazywane przez 73\% spośród nich, osobiste korzyści związane z możliwością zdobycia nowych umiejętności i wiedzy (wskazane przez 42\% z nich i 25\% pozostałych) oraz spędzenia czasu w sposób ciekawy (wskazane przez 36\% z nich i $24 \%$ pozostałych). Warto odnotować także, że wśród badanych ze wsi znalazł się znacząco wyższy odsetek osób (58\% kategorii), dla których istotny motywator do działania stanowiły relacje towarzyskie i społeczne, niż działo się to w przypadku badanych zamieszkujących w miastach (46\% kategorii) (Zaangażowanie... 2014).

Osoby nie angażujące się w działalność społeczną (czyli zdecydowana większość polskiego społeczeństwa) wskazują na szereg przeszkód i barier pojawiających się na drodze do podjęcia takiej aktywności. Są 
to przede wszystkim osobiste problemy i sprawy, o które trzeba się zatroszczyć w pierwszej kolejności, a które pochłaniają cały czas (rodzina, bieżące problemy, obowiązki zawodowe/szkolne), brak wiedzy na temat możliwości działania, brak informacji o organizacjach prowadzących działalność społeczną, brak wiary we własne umiejętności oraz w powodzenie działań podejmowanych przez organizacje, ogólny brak zaufania do ludzi, niechęć do działania (por. Zaangażowanie... 2014; TNS... 2013). Według raportu stowarzyszenia Klon/Jawor argumentami stosowanymi stosunkowo częściej przez mieszkańców wsi niż miast były brak wiedzy i pomysłu na działanie ( $82 \%$ osób z tej kategorii, przy 74\% mieszkańców miast liczących powyżej 50 tysięcy mieszkańców), nieznajomość ludzi lub organizacji, z którymi można by zacząć działać (53\% badanych ze wsi i małych miast przy 44\% mieszkańców miast mających powyżej 50 tysięcy mieszkańców), brak wiedzy na temat tego, jak zaangażować się w tego typu działania i gdzie znaleźć informacje na ten temat ( $51 \%$ badanych ze wsi i $40 \%$ badanych z miast), niepewne, niewystarczające korzyści z zaangażowania w działalność tego typu - 24\% mieszkańców wsi i 14\% mieszkańców miast (Zaangażowanie... 2014: 55-58). Co warte zauważenia, na istnienie barier mogących skutkować powyższą argumentacją (ale także stojącym za nią brakiem aktywności) wskazują także osoby zaangażowane w wolontariat. Z ich perspektywy podstawowe bariery popularyzacji wolontariatu wynikają z

nieprzygotowania organizacji do pracy z nimi, poczynając od niedostatecznej informacji, mało przyciagających, wąsko zakrojonych [działań] komunikacyjnych (pod względem adresata, kanałów dotarcia, bogactwa przekazu), na nieumiejętności zagospodarowania potencjału wolontariuszy kończąc (Dziarmakowska, Olesińska 2011: 20).

Przynależność do organizacji i praca (nieodpłatna) na rzecz innych osób nie są jedynymi przejawami aktywności społecznej. W jej ramach lokuje się także zainteresowanie sprawami kraju, w tym polityką, oraz „najbardziej powszechne doświadczenie obywatelskie” (Sułek 2013: 281), jakim jest udział w wyborach. Mimo jego relatywnej (np. w odniesieniu do omawianych obszarów aktywności) powszechności, także w wyborach parlamentarnych, samorządowych i prezydenckich Polacy uczestniczą niezbyt licznie. Frekwencja w dwóch pierwszych ty- 
pach wyborów zazwyczaj nie przekracza $50 \%{ }^{38}$ (w ostatnich wyborach parlamentarnych wyniosła 48,9\%, w wyborach zaś samorządowych $47,3 \%$ ), osiagając nieco wyższą wartość w wyborach prezydenckich (w ostatnich wyborach wyniosła 55,3\%). Co warte podkreślenia,

poczynając od wyborów 2005 roku, poziom wyborczego uczestnictwa mieszkańców wsi wyraźnie odbiegał od rejestrowanego w miastach [...] W wyborach parlamentarnych w 2011 roku, w miastach głosowało 54,52\% uprawnionych, na wsi 42,42\% [...] w 2007 roku w wyborach tych udział wzięło 58,8\% mieszkańców miast, na wsi zaś głosowało tylko 45,3\% uprawnionych [...] w 2005 roku udział wyborców wiejskich był o 7 punktów procentowych niższy niż wyborców w miastach (CBOS 2014: 2).

Podobne prawidłowości można zaobserwować w analizach dotyczących zainteresowania polityką jako takiego.

Nikłe lub wręcz żadne zainteresowanie tą sferą życia deklaruje ponad połowa badanych zamieszkujących na wsi (52\%), a jedynie co piętnasty określa swoje zainteresowanie wydarzeniami politycznymi jako duże (7\%). Spośród mieszkańców miast do wyraźnie zainteresowanych życiem politycznym zalicza się dwukrotnie więcej osób (14\%). Także mniej lub bardziej zdecydowane désintéressement wobec polityki w miastach wyrażane jest rzadziej niż na wsi (46\%) (CBOS 2014: 1).

Na szczególną uwagę zasługują w tym kontekście także wyniki analiz dotyczących zainteresowania polityką i partycypacją w wyborach młodzieży w wieku 15-17 lat, nie mającej jeszcze praw wyborczych, przeprowadzonych przez Centrum Badania Opinii Społecznej (CBOS) w roku 2012. Chęć uczestnictwa w głosowaniu (gdyby wybory odbywały się w momencie realizacji badania) zadeklarowało zaledwie 38\% badanych z kategorii 15-17 lat (przy 56\% takich deklaracji wśród ogółu dorosłych Polaków), a niemal taki sam odsetek tej grupy (34\%) stwierdził, że nie wziąłby w nich udziału, nawet gdyby mógł. Jak konkluduje autor raportu:

38 Poza rokiem 1993, kiedy to frekwencja w wyborach parlamentarnych wyniosła 52,1\% i wyborami parlamentarnymi 2007 r., w których uczestniczyło 53,9\% uprawnionych. 
kontestujące nastawienie wobec procedur demokratycznych, czy generalnie niechęć do polityki, maleje wraz z wiekiem. Jednak nawet w grupie siedemnastolatków, którzy do końca 2012 roku nabędą prawa wyborcze, poziom alienacji politycznej ciagle pozostaje wysoki - prawie jedna trzecia z nich odmówiłaby udziału w wyborach (CBOS 2012: 2).

Podsumowując - ogólnopolskie badania nad aktywnością społeczną Polaków (zarazem warunkowaną ich kapitałem ludzkim i społecznym, jak i będącą ich konsekwencją) ukazują znaczące niedostatki we wszystkich analizowanych obszarach (poziomie kompetencji kluczowych niezbędnych do funkcjonowania w społeczeństwie informacyjnym i gospodarce opartej na wiedzy, poziomie zaufania społecznego umożliwiającego kooperację z różnymi podmiotami, w różnych obszarach życia społecznego, aktywności stowarzyszeniowej i pracy w ramach szeroko rozumianego wolontariatu, poziomie uczestnictwa w podstawowych procedurach demokratycznych). Co szczególnie niepokojące, wszystkie te diagnozy dotyczą w największym stopniu mieszkańców obszarów wiejskich, a większość z nich dotyka zwłaszcza młodzieży.

\section{Młodzi aktywni - przykład członków Lokalnych Grup Działania}

Charakteryzując aktywność społeczno-polityczną mieszkańców wsi z jednej strony wskazuje się na jej stosunkowo niewielki zakres, z drugiej jednak zwraca się uwagę na, wynikającą z charakteru społeczności wiejskiej, specyfikę tejże aktywności. Według niektórych analityków omawianej problematyki płaszczyznę potencjalnej aktywności i budowy kapitału społecznego wsi stanowią instytucje i inicjatywy wyrastające bezpośrednio z zaplecza kulturowego tych obszarów i skierowane wprost do ich mieszkańców.

Należą do nich stowarzyszenia (przede wszystkim Ochotnicze Straże Pożarne oraz towarzystwa sportowe), inicjatywy i grupy skupione wokół Kościoła katolickiego, organizacje gospodarcze (kółka rolnicze i maszynowe, grupy i zrzeszenia producentów), tzw. komitety społeczne, czy tradycyjne inicjatywy kulturalne i zawodowe (często wtopione w struktury innych organizacji), takie na przykład jak orkiestry strażackie, Koła Gospodyń Wiejskich, zespoły ludowe przy Kółkach Rolniczych (Herbst 2008: 173), 
ale także nowe formy zagospodarowywania potencjału mieszkańców wsi, takie jak inicjatywy oświatowe i ruch odnowy wsi czy Lokalne Grupy Działania, powoływane $\mathrm{z}$ wykorzystaniem podejścia LEADER ${ }^{39}$ (por. Wilkin 2008; Budzich-Szukała 2008).

W związku z tym, w celu uzupełnienia obrazu aktywności społeczno-politycznej młodzieży wiejskiej - skonstruowanego na podstawie wyników badań realizowanych w większości na reprezentatywnych próbach dorosłych Polaków - o wskazany wymiar, poniżej przedstawiona zostanie charakterystyka aktywności młodych mieszkańców wsi urzeczywistnianej w ramach ostatniego z wymienionych typów organi$\mathrm{zacji}^{40}$.

Członkowie lokalnych grup działania mający nie więcej niż 34 lata to zaledwie $14 \%$ składu badanych organizacji ( 82 osoby na 570 uczestniczących $\mathrm{w}$ badaniu ${ }^{41}$ ). W zdecydowanej większości (82\% kategorii) są to osoby urodzone $\mathrm{w}$ gminie, na terenie której działają w lokalnej grupie (taki rodowód charakteryzuje $2 / 3$ spośród starszych członków organizacji), niemal w równym stopniu kobiety (51\% ogółu) i mężczyźni (49\%), podczas gdy w grupie starszych członków organizacji większość stanowią mężczyźni (59\% ogółu). Jako kategoria są zdecydowanie

39 Zgodnie z założeniami lokalne grupy działania przybierają postać stowarzyszeń, związków stowarzyszeń lub fundacji. Prowadzą aktywność na podstawie lokalnych strategii rozwoju, sformułowanych z wykorzystaniem analizy sytuacji danego obszaru (jego zasobów i potrzeb). Proponowana formuła organizacji - partnerstwo pomiędzy sektorami publicznym, prywatnym i cywilnym na poziomie lokalnym oparte jest na dobrowolnej współpracy różnych kategorii aktorów funkcjonujących w lokalnej przestrzeni (przy minimum pięćdziesięcioprocentowym udziale przedstawicieli lokalnych podmiotów społecznych i gospodarczych).

40 Dane empiryczne zaczerpnięto $\mathrm{z}$ badań przeprowadzonych w ramach projektu „Struktura i uwarunkowania kapitału społecznego lokalnych grup działania”, metodą ankiety indywidualnej na próbie 573 członków 34 Lokalnych Grup Działania z województw małopolskiego, lubuskiego, opolskiego, podkarpackiego, wielkopolskiego i zachodniopomorskiego, rozdysponowanej wśród członków LGD. Projekt zrealizowano na podstawie umowy z Narodowym Centrum Nauki 6996/B/H03/2011/40, w latach 2011-2013.

41 Próba nie miała charakteru reprezentatywnego dla wszystkich organizacji tego typu, w związku z czym nieuprawnione byłoby wnioskowanie o ich składzie. 
lepiej wykształceni od swoich starszych kolegów. Aż 84\% spośród nich ma wykształcenie powyżej średniego (z czego $72 \%$ ukończyło studia wyższe, a $12 \%$ je kontynuuje). W kategorii 35 i więcej lat wykształceniem wyższym legitymuje się $57 \%$ badanych, a kolejne $3 \%$ z nich kontynuuje studia. Większość młodych członków LGD pracuje (88\% grupy), niemal wszyscy poza rolnictwem. (Podczas gdy prace w rolnictwie deklarują tylko dwie osoby z kategorii 18-34 lata, wśród starszych pracujących członków LGD odsetek osób związanych z rolnictwem wynosi $12 \%$ ).

Większość działaczy lokalnych grup działania $(70 \%$ młodych i wszyscy starsi), niezależnie od pracy w tej organizacji udzielała się także w innych formach i obszarach aktywności społecznej, co wskazuje, że na tle ogółu społeczeństwa polskiego jest to grupa wyjątkowa. Największe grupy badanych (73\% osób, które ukończyły 35 lat i 59\% młodszych) angażowały się w inicjatywy związane z szeroko rozumianym promowaniem lokalnej kultury (m.in. w organizacje wystaw, odczytów, festynów, różnego typu festiwali i uroczystych obchodów świąt), zgłaszały rozmaite postulaty do władz lokalnych (79\% badanych z kategorii wiekowej 35 i więcej lat i 49\% badanych z kategorii od 18 . do 34. roku życia), pracowały w organizacjach pozarządowych (51\% działaczy w wieku co najmniej 35 lat i 57\% młodszych członków grupy) i uczestniczyły w akcjach zorganizowanych przez mieszkańców gminy na rzecz realizacji wspólnej sprawy (odpowiednio 49 i 44\% porównywanych kategorii).

Zestawienie wszystkich obszarów aktywności zadeklarowanych przez członków badanych grup przedstawiono w tabeli 14 .

W świetle zaprezentowanych głównych obszarów aktywności społecznej członków lokalnych grup działania nie budzi zaskoczenia fakt, że przedstawiciele kategorii wiekowej 18-34 lata reprezentuja w ramach swoich organizacji głównie sektor społeczny (67\% spośród nich, przy niespełna $50 \%$ osób należących do innych kategorii wiekowych) i zdecydowanie rzadziej niż starsi członkowie organizacji piastują w nich funkcje decyzyjne, co ujęto szczegółowo w tabeli 15. 
Tabela 14

Obszary aktywności społecznej członków LGD według kategorii wiekowych (w \%)

\begin{tabular}{|l|c|c|}
\hline \multirow{2}{*}{\multicolumn{1}{c|}{ Obszary aktywności }} & \multicolumn{2}{c|}{$\begin{array}{c}\text { Odsetek członków LGD } \\
\text { zaangażowanych w daną działalność }\end{array}$} \\
\cline { 2 - 3 } & $\begin{array}{c}\text { w wieku } \\
18-34 \text { lat }\end{array}$ & $\begin{array}{c}\text { w wieku } \\
\text { 35 i więcej lat }\end{array}$ \\
\hline Udział w promowaniu lokalnej kultury & 59 & 73 \\
\hline Praca w organizacji pozarządowej & 57 & 51 \\
\hline Zgłoszenie postulatu do władz lokalnych & 49 & 79 \\
\hline $\begin{array}{l}\text { Udział w akcji zorganizowanej przez miesz- } \\
\text { kańców na rzecz realizacji wspólnej sprawy }\end{array}$ & 44 & 49 \\
\hline $\begin{array}{l}\text { Zaangażowanie w inne inicjatywy na rzecz } \\
\text { mieszkańców }\end{array}$ & 43 & 53 \\
\hline Udział w proteście & 28 & 39 \\
\hline $\begin{array}{l}\text { Zgłoszenie przedsięwzięcia do lokalnych } \\
\text { instytucji }\end{array}$ & 21 & 34 \\
\hline Zainicjowanie protestu & 5 & 4 \\
\hline
\end{tabular}

Uwaga: odsetki przedstawione w poszczególnych kolumnach tabeli nie sumują się do 100, ponieważ możliwe było udzielenie więcej niż jednej odpowiedzi.

Źródło: opracowanie własne.

Tabela 15

Pozycja młodych członków LGD w strukturze organizacji (w \%)

\begin{tabular}{|l|l|r|r|}
\hline \multicolumn{2}{|c|}{ Struktura organizacji } & $\begin{array}{c}\text { Członkowie LGD } \\
\text { w wieku 18-34 lat } \\
\text { N=82 }\end{array}$ & $\begin{array}{c}\text { Członkowie LGD } \\
\text { w wieku 35 i więcej lat } \\
\text { N = 488 }\end{array}$ \\
\hline \multirow{4}{*}{ Sektor } & publiczny & 19,5 & 29,7 \\
\cline { 2 - 5 } & gospodarczy & 13,4 & 20,4 \\
\cline { 2 - 5 } & społeczny & 67,1 & 49,9 \\
\hline \multirow{2}{*}{$\begin{array}{l}\text { Funkcja } \\
\text { w LGD }\end{array}$} & członek zarządu & 12,3 & 24,2 \\
\cline { 2 - 5 } & członek rady & 13,6 & 34,4 \\
\cline { 2 - 5 } & członek komisji rewizyjnej & 3,7 & 6,9 \\
\hline
\end{tabular}

Źródło: opracowanie własne. 
Także w realizację inicjatyw podejmowanych w ramach grupy angażuje się nieco mniejszy - w stosunku do grupy osób, które ukończyły 35. rok życia - odsetek młodych działaczy LGD (różnica między porównywanymi kategoriami wynosi w tym przypadku niespełna pięć punktów procentowych). Za to stosunkowo większa część tej kategorii, niż kategorii 35+, deklaruje wyłącznie formalne członkostwo w organizacji (różnica wynosi tu już niemal dziewięć punktów procentowych (por. tabela 16).

Tabela 16

Forma aktywności młodych członków LGD w organizacji (w \%)

\begin{tabular}{|c|c|c|c|}
\hline \multicolumn{2}{|c|}{ Wyszczególnienie } & $\begin{array}{c}\text { Członkowie LGD } \\
\text { w wieku 18-34 lat } \\
\mathrm{N}=82\end{array}$ & $\begin{array}{c}\text { Członkowie LGD } \\
\text { w wieku } 35 \text { i więcej lat } \\
\mathrm{N}=488\end{array}$ \\
\hline \multirow{3}{*}{$\begin{array}{l}\text { Typ } \\
\text { aktywności } \\
\text { w LGD }\end{array}$} & formalne członkostwo & 22,2 & 13,5 \\
\hline & $\begin{array}{l}\text { zabieranie głosu na } \\
\text { zebraniach }\end{array}$ & 27,2 & 31,3 \\
\hline & $\begin{array}{l}\text { działanie przy realizacji } \\
\text { inicjatyw LGD }\end{array}$ & 50,6 & 55,3 \\
\hline
\end{tabular}

Źródło: opracowanie własne.

Być może, podobnie jak wyglądało to w przypadku ogółu młodych Polaków, także aktywność młodych członków lokalnych grup działania podlega przede wszystkim ograniczeniom wynikającym z fazy cyklu życia, w której się oni znajdują (związanej przede wszystkim z nagromadzeniem obowiązków wynikających z założenia rodziny i pojawienia się dzieci). Zwłaszcza, że „w 2013 r. po raz kolejny nastąpiło pogłębienie zróżnicowania przestrzennego dostępu do usług edukacyjno-opiekuńczych między miastem (nawet małym) a wsią, podobnie jak w latach 2000-2009" (Grabowska et al. 2013: 84), co niewatpliwie nie ułatwia godzenia pracy zawodowej (dla przypomnienia - niemal 90\% młodych członków LGD pracuje), aktywności w organizacji i życia rodzinnego.

Jedną z przyczyn relatywnie (w stosunku do członków starszych) niskiego poziomu aktywności młodych członków LGD i ich niskiej pozycji w organizacji może być także specyfika tych struktur związana 
$\mathrm{z}$ jednej strony $\mathrm{z}$ ich profesjonalizacją (warunkującą udział w określonych przedsięwzięciach posiadaniem określonych kompetencji wypracowywanych w długoletniej praktyce), z drugiej z charakterem relacji łączących jej członków (w ramach sektorów i kategorii społeczno-demograficznych - osobistych, ciepłych i opartych na zaufaniu, pomiędzy sektorami i kategoriami raczej zdystansowanych i nieufnych) (por. Psyk-Piotrowska et al. 2013). Ostatnią interpretację dodatkowo uprawdopodabnia deklarowany przez badanych poziom zaufania do różnych kategorii osób. Młodzi członkowie LGD, częściej niż starsi, są skłonni ufać wyłącznie członkom własnej rodziny i zachowywać dystans do osób obcych. Zaufanie do rodziny deklaruje $98 \%$ młodych i $95 \%$ starszych, przy czym wśród młodych brak jest osób, które rodzinie nie ufają. Z odwrotną relacją mamy do czynienia w przypadku zaufania do osób nieznajomych. Brak zaufania do obcych deklaruje $42 \%$ młodych i 32\% starszych członków LGD. Także odsetek osób deklarujących ogólne zaufanie do ludzi jest nieco niższy wśród młodszych członków LGD (niespełna $61 \%$ kategorii), niż wśród starszych (68\% tej grupy).

Istotną barierą aktywności młodych członków LGD wydaje się także ograniczone zaufanie do władz lokalnych (deklaruje je niespełna co trzeci z nich, podczas gdy deklarację taką składa $47 \%$ osób starszych) połączone z niskim poczuciem sprawczości i wpływu na działania i decyzje władz. Niespełna co czwarty spośród młodych działaczy (24\% kategorii) uważa, że decydującą rolę w rozwiązywaniu problemów gminy i jej mieszkańców powinni odegrać sami mieszkańcy, 39\% z nich ma poczucie, że aktywność osób, takich jak oni, może przyczynić się do rozwiązywania problemów gminy, co czwarty ocenia swój wpływ na decyzje władz lokalnych jako ponadprzeciętny. Wśród osób starszych analogiczne przekonania deklaruje odpowiednio 33, 70 i 47\% kategorii. Zestawienie wszystkich deklaracji zaprezentowano w tabeli 17.

Wśród uzasadnień braku rzeczywistej aktywności w ramach organizacji sami członkowie LGD przywołują w większości argumenty analogiczne do pojawiających się w ogólnopolskich badaniach nad aktywnością społeczną Polaków: brak czasu (ponad połowa młodych i co trzeci spośród starszych), poczucie braku wystarczających kompetencji do realizacji konkretnych działań (co trzeci z młodych i 40\% starszych) 
产

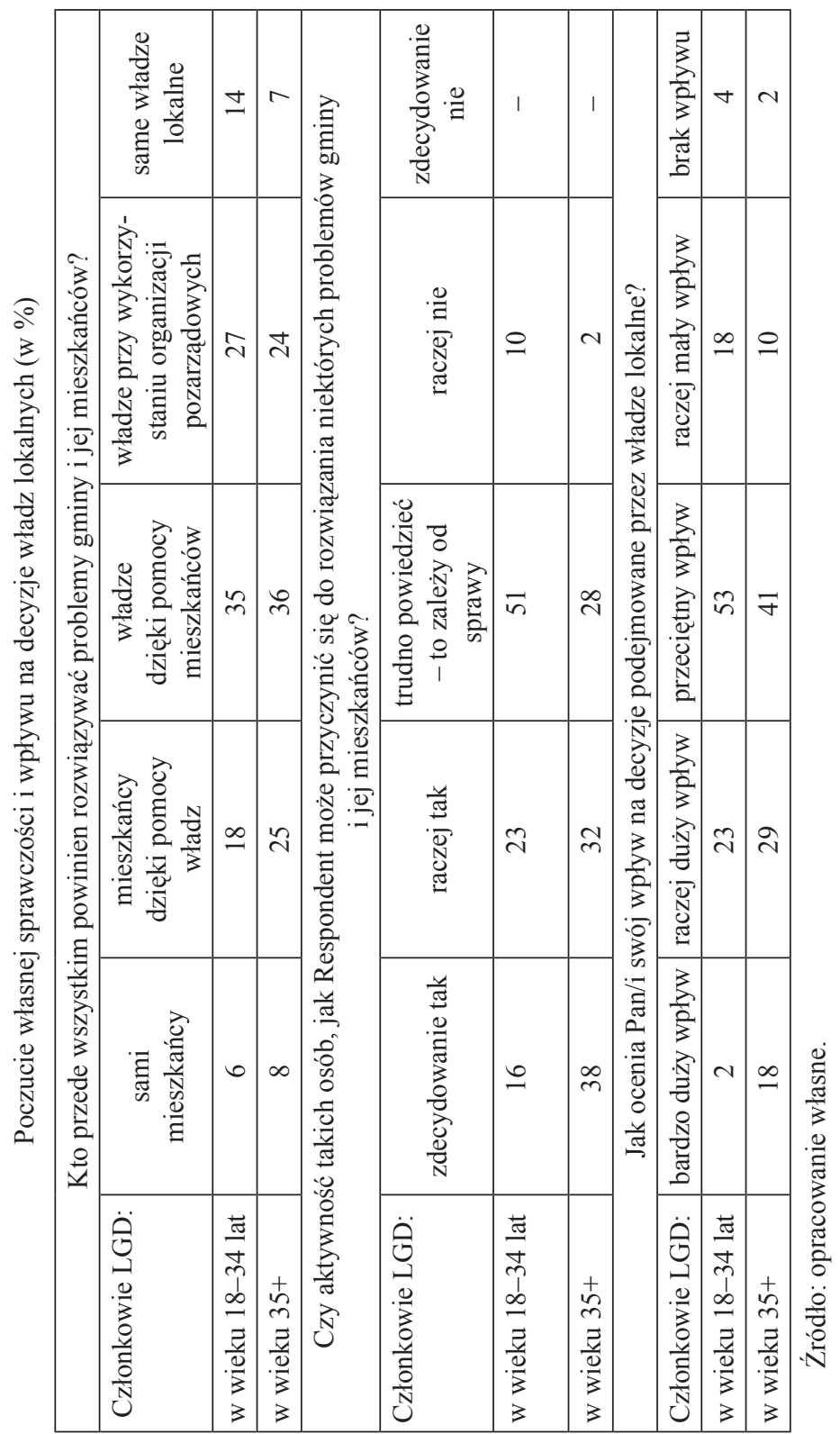


i doświadczenia we współpracy w LGD (co ciekawe tylko jedna osoba z kategorii wiekowej 18-34 lata i aż co czwarta z kategorii 35 i więcej lat), brak wystarczających informacji na temat realizowanych inicjatyw (17\% młodych i 9\% starszych), czy w końcu brak możliwości wykazania się $w$ działaniach, związany z faktem, że zawsze realizują je te same osoby, do grona których badany, mimo chęci uczestnictwa w danej inicjatywie, nie został włączony (11\% młodych i 15\% starszych). Zestawienie wypowiedzi obu kategorii przedstawiono na wykresie 2 .

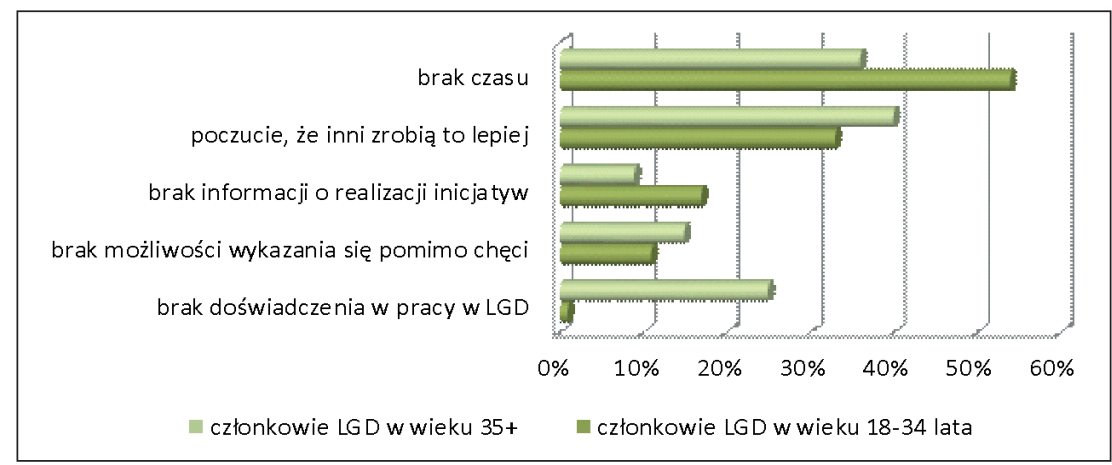

Wykres 2. Uzasadnienie braku uczestnictwa w inicjatywach LGD Źródło: opracowanie własne

Ostatnim obszarem aktywności społeczno-politycznej członków lokalnych grup działania poddanym analizie jest ich zainteresowanie polityką i udział w wyborach. Podobnie jak wyglądało to w przypadku pozostałych obszarów, młodzi działacze organizacji wyróżniają się korzystnie na tle swoich rówieśników, ale wypadają słabiej w porównaniu ze starszymi członkami własnej organizacji. Ponadprzeciętne zainteresowanie (bardzo duże lub duże) polityką zadeklarowało 38\% badanych, którzy nie ukończyli 35. roku życia i 56\% starszych, zainteresowanie zaś przeciętne $46 \%$ młodych i $36 \%$ starszych. Więcej niż co ósmy badany (12\%) z kategorii młodszych w ogóle nie interesował się polityką, a 4\% spośród nich interesowało się nią jedynie w niewielkim stopniu (tylko $1 \%$ starszych deklaruje całkowity brak zainteresowania tą sferą życia, a 6\% osób z tej kategorii interesuje się nią tylko w niewielkim stopniu). 
Dość wyraźnie zróżnicowany poziom zainteresowania polityką przedstawicieli każdej z porównywanych kategorii wiekowych nie znajduje odzwierciedlenia $\mathrm{w}$ ich partycypacji w głosowaniach w ramach wyborów. Udział w wyborach prezydenckich deklaruje po 78\% członków każdej z nich, udział w wyborach parlamentarnych 75\% osób, które w momencie realizacji badań ukończyły co najmniej 35. rok życia i 72\% osób młodszych, udział zaś w wyborach samorządowych $89 \%$ osób starszych (35+) i 84\% osób młodszych (por. tabela 18).

Tabela 18

Udział członków badanych LGD w wyborach (w \%)

\begin{tabular}{|c|c|c|}
\hline \multirow{2}{*}{ Forma aktywności politycznej } & \multicolumn{2}{|c|}{$\begin{array}{l}\text { Odsetek członków LGD zaangażowanych } \\
\text { w daną działalność }\end{array}$} \\
\hline & w wieku 18-34 lata & w wieku 35 i więcej \\
\hline Udział w wyborach prezydenckich & 78 & 78 \\
\hline Udział w wyborach parlamentarnych & 72 & 75 \\
\hline Udział w wyborach samorządowych & 84 & 89 \\
\hline
\end{tabular}

Źródło: opracowanie własne.

Mając na uwadze fakt, że poziom uczestnictwa w wyborach szacowany na podstawie deklaracji zazwyczaj jest wyższy w stosunku do uczestnictwa rzeczywistego, warto jednak podkreślić jego szczególnie wysokie wskaźniki w przypadku badanych członków lokalnych grup działania (zwłaszcza w odniesieniu do wyborów samorządowych).

\section{Podsumowanie}

Diagnozowana w zasadzie we wszystkich kategoriach społeczno-demograficznych niska aktywność zrzeszeniowa, wspólnotowa, polityczno-społeczna i prospołeczna skutkuje brakiem

okazji, by się nauczyć zorganizowanego działania społecznego i nabyć umiejętności potrzebnych do życia w społeczeństwie obywatelskim. Polacy nie umieją się organizować i skutecznie działać wspólnie [...]. Nie umieją, bo się tego nie nauczyli z ich, ubogiego, doświadczenia. Nie umieją, bo nie działają a nie działają bo nie umieją... (Sułek 2013: 283-284) 
Co oczywiste, wskazany problem - zarówno z racji wieku i związanego z nim życiowego doświadczenia, jak i braku możliwości czerpania bezpośrednich wzorców z najbliższego otoczenia - dotyczy przede wszystkim osób młodych. W największym stopniu tych, które na drodze do uczestnictwa w życiu społecznym napotykają relatywnie dużo barier (komunikacyjnych, technologicznych, ekonomicznych) związanych ze specyfiką ich miejsca zamieszkania (jak dzieje się w przypadku obszarów wiejskich). Jednocześnie to dla nich właśnie rozwiązanie tego problemu ma szczególne znaczenie. To one większość swojego życia spędzą funkcjonując w społeczeństwie (i na rynku pracy) coraz wyraźniej i brutalniej „,upominającym się" o brakujące umiejętności i kompetencje (pozyskiwania z różnych źródeł i przetwarzania dużej liczby informacji, gotowość i umiejętność przyswajania nowych wiadomości, komunikacji interpersonalnej, współorganizowania rozmaitych przedsięwzięć i współdziałania dla ich realizacji, przewidywania konsekwencji dokonywanych wyborów). I, jak pokazuja przytoczone badania, możliwość „trenowania” tych kompetencji, uzyskanie konkretnych, wymiernych (bo przekładających się na niemożliwe do zdobycia gdzie indziej umiejętności i doświadczenia) korzyści staje się, obok możliwości interesującego zagospodarowania wolnego czasu, jednym z głównych motywatorów skłaniających młodzież do podejmowania aktywności społecznej (por. Zaangażowanie... 2014). Wykorzystany w artykule przykład młodych członków lokalnych grup działania utwierdza w przekonaniu, że płaszczyzną umożliwiającą w największym zakresie realizowanie tych motywacji jest działalność społeczna prowadzona na poziomie lokalnych społeczności i grup, w ramach których jednostki na co dzień funkcjonują (organizacji pozarządowych, stowarzyszeń, fundacji, wolontariatu, lobbingu i protestów w różnych sprawach).

\section{Bibliografia}

Budzich-Szukała U., 2008, Program LEADER w Polsce - sposób na aktywizację wsi, [w:] Polska wieś 2008. Raport o stanie wsi, red. J. Wilkin, I. Nurzyńska, Fundacja na Rzecz Rozwoju Polskiego Rolnictwa, Warszawa

CBOS, 2012, Pokolenie przysztych wyborców - preferencje partyjne niepetnoletnich Polaków, Raport BS/79/2012 
CBOS, 2014, Postawy mieszkańców wsi wobec polityki, Raport nr 30/2014

Czapiński J., 2013, Stan społeczeństwa obywatelskiego. Kapitał społeczny. Diagnoza Społeczna 2013. Warunki i Jakość Życia Polaków - Raport (Special issue), „Contemporary Economics", 7: 285-297

Działek J., 2011, Kapitał społeczny jako czynnik rozwoju gospodarczego w skali regionalnej i lokalnej w Polsce, Wydawnictwo UJ, Kraków

Dziarmakowska K., Olesińska J., 2011, To jest wolontariat. Raport z badania „Kodeks kluczowych wartości wolontariatu”, Pracownia Badań i Innowacji Społecznych „Stocznia” dla Fundacji Dobra Sieć - http://www.projektor.org.pl/uploads/184_1. pdf (dostęp: 10.09.2014)

Florida R., 2010, Narodziny klasy kreatywnej, Narodowe Centrum Kultury, Warszawa Fukuyama F., 1997, Zaufanie. Kapitat społeczny a droga do dobrobytu, PWN, Warszawa Furmankiewicz M., 2013, Wspótrzqdzenie czy ukryta dominacja sektora publicznego? Koncepcja governance w praktyce lokalnych grup działania, „Studia Regionalne i Lokalne", 1 (51): 71-89

Górniak J. (red.), 2013, Młodość czy doświadczenie? Kapital ludzki w Polsce, Raport z badań realizowanych w ramach projektu Bilans Kapitału Ludzkiego w Polsce (BKL), Warszawa

Grabowska I., Węziak-Białowolska D., Kotowska I. E., Panek T., 2013, Warunki życia gospodarstw domowych. Edukacja i kapitat ludzki. Diagnoza Społeczna 2013 Warunki i Jakość Życia Polaków - Raport (Special issue), „Contemporary Economics”, 7: 84-102

Główny Urząd Statystyczny, 2013, Wolontariat w organizacjach i inne formy pracy niezarobkowej poza gospodarstwem domowym - 2011. Studia i analizy statystyczne, Warszawa

Herbst J., 2005, Oblicza społeczeństwa obywatelskiego, Fundacja Rozwoju Społeczeństwa Obywatelskiego, Warszawa

Herbst J., 2008, Wieś obywatelska, [w:] J. Wilkin, I. Nurzyńska (red.), Polska wieś 2008. Raport o stanie wsi, Fundacja na Rzecz Rozwoju Polskiego Rolnictwa, Warszawa: 159-179

Herbst M. (red.), 2007, Kapitał ludzki i kapitał społeczny a rozwój regionalny, Scholar, Warszawa

Kaźmierczak T., 2011, Partycypacja publiczna: pojęcie, ramy teoretyczne, [w:] A. Olech (red.), Partycypacja publiczna. O uczestnictwie obywateli w życiu wspólnoty lokalnej, Fundacja Instytut Spraw Publicznych, Warszawa

Matusiak K., Kuciński J., Gryzik A., 2009, Foresight kadr nowoczesnej gospodarki, PARP, Warszawa http://www.parp.gov.pl/files/74/81/305/5266.pdf (dostęp: 6.12.2013)

Perspektywa uczenia się przez całe życie, 2013, dokument programowy Międzyresortowego Zespołu ds. uczenia się przez całe życie, w tym Krajowych Ram Kwalifikacji, http://bip.men.gov.pl/images/stories/Karolina/pll12011_02_04.pdf (dostęp: 10.11.2013) 
Psyk-Piotrowska E., Zajda K., Kretek-Kamińska A., Walczak-Duraj D., 2013, Struktura $i$ uwarunkowania kapitatu społecznego lokalnych grup działania, Wydawnictwo Uniwersytetu Łódzkiego, Łódź

Putnam R, 2008, Samotna gra w kręgle. Upadek i odrodzenie wspólnot lokalnych w Stanach Zjednoczonych, Wydawnictwa Akademickie i Profesjonalne, Warszawa

Sartori G., 1998, Teoria demokracji, PWN, Warszawa

Strzelecki P., Saczuk K., Grabowska I., Kotowska I. E., 2013, Warunki życia gospodarstw domowych. Rynek pracy. Diagnoza Społeczna 2013, Warunki i Jakość Życia Polaków - Raport (Special issue), „Contemporary Economics”, 7: 122-152

Sułek A., 2013, Stan spoleczeństwa obywatelskiego. Doświadczenie, działania dla społeczności i kompetencje obywatelskie. Diagnoza Społeczna 2013, Warunki i Jakość Życia Polaków - Raport (Special issue), „Contemporary Economics, 7: $275-284$

TNS Polska, 2013, Zaangażowanie społeczne Polaków, Raport dla Groupon Polska http://media.groupon.pl/pr/248685/razem-mozemy-wiecej-polacy-wola-dzialacw-grupie-niz-w-pojedynke (dostęp: 10.09.2014)

Triglia C., 2001, Social Capital and Local Development, „European Journal of Social Theory", 4 (4): 427-442

Wilkin J., 2008, Samoorganizacja i ożywienie społeczno-gospodarcze na wsi. Przeglad najważniejszych zjawisk, [w:] Polska wieś 2008. Raport o stanie wsi, red. J. Wilkin, I. Nurzyńska, Fundacja na Rzecz Rozwoju Polskiego Rolnictwa, Warszawa

Zaangażowanie społeczne Polek i Polaków - raport z badania 2013, 2014, Stowarzyszenie Klon/Jawor http://civicpedia.ngo.pl/wiadomosc/978536.html (dostęp: 10.09.2014)

\section{Social Activity of Young Inhabitants of Rural Areas. (The Case of the LAGs Members)}

Summary:

Framework documents referring to effective management at different levels of public administration, making use of the theory of democracy, strongly point out the meaning and importance of participation of citizens in public decision making. The attention is also drawn to the growing role of social and human capital in the concepts of knowledge-based society and economy based on knowledge and information. They are expressed in social activity and become one of the key factors of development and competitiveness of contemporary societies and economies (local, regional or national). Obviously, this kind of capital is crucial and demanded in the rural areas where their deficit is really visible (especially when it is accompanied by the deficit of other resources which can potentially generate the development of a given area). 
This chapter is an attempt to analyze the level and scope of social activity among young inhabitants of rural areas, perceived as the notion of social capital of this category. Its aim is a description of the main areas and character of this activity together with the diagnosis of, at least, some most vital correlates of it.

Keywords: social activity, human capital, social capital, volunteering, young inhabitants of rural areas. 